\title{
Necati Cumalı Şiirlerinde Modernliğin Eleştirisi
}

\author{
Dr. Öğr. Üyesi Burak ÇAVUŞ \\ Gazi Osman Paşa Üniversitesi \\ Erbaa Sosyal ve Beşeri Bilimler Fakültesi \\ Türk Dili ve Edebiyatı Bölümü \\ burak.cavus@gop.edu.tr
}

ORCID: 0000-0002-5050-6523

\begin{abstract}
Öz
Bu çalışmada, Necati Cumalı'nın Tufandan Önce (1983) adlı şiir kitabındaki şiirleri üzerinden sanatçının modernliğin sonuçlarına yaklaşımı incelenmiştir. Cumalı'nın modernliğe bakışı ve modernliğin sonucunda ortaya çıkan yeni koşulları özellikle de Tufandan Önce ve Sonumuz Bu Muydu şiirlerinde yoğunlaşı̆̆ı için bu iki şiir örneklem olarak alınmıştır. Bu şiirlerde Cumalı, modern endüstriyel yaşamın belirleyicileri çerçevesinde ortaya çıkan yeni oluşumlar karşısında insanlığın geldiği noktayı sorgulamış ve eleştirmiştir. Incelemenin odak noktası da bu sorgulama ve eleştiriler olmuş; modernliğin sonuçları bağlamında üretilen çeşitli teorilerle Cumalı'nın şiirlerinde görülen ilişki üzerinde durulmuştur. Ayrıca şairin, George Orwell'ın 1984 (2019) ve Aldous Huxley'in Cesur Yeni Dünya (2020) gibi distopik romanlarla kurduğu metinlerarası ilişki de dikkate alınmış gerek teorik gerek kurgusal olarak modern dünyayı anlamlandırmaya yönelik çalışmalar doğrultusunda Cumalı'nın dikkat çektiği modernlik koşulları ve pratikleri tespit edilmiştir. Bu noktada gözetim toplumu, tüketim toplumu gibi teorilerle birlikte yine modernlikle ilişkili olarak gündeme gelen gündelik hayat, medya, panoptikon, güvenlik, risk, metalaşma, cinsellik, yalnızlık ve yabancılaşma gibi kavramlar çerçevesinde şiirler irdelenmiştir.
\end{abstract}

Anahtar Kelimeler: necati cumalı, şiir, modernliğin eleştirisi, modernliğin sonuçları.

Çavuş, B. (2021). Necati Cumalı Şiirlerinde Modernliğin Eleştirisi. ARTS: Artuklu Sanat ve Beşeri Bilimler Dergisi, Necati Cumalı Özel Sayısı, ss. 74-89. 


\title{
$\operatorname{arts}=$
}

Research Article

\section{Criticism of Modernity in Necati Cumalı Poems}

\begin{abstract}
In this study, the approach of the artist to the consequences of modernity was examined through the poems of Necati Cumalı in his poetry book, Before the Flood (1983). These two poems were taken as samples, since Cumalı's view of modernity and the new conditions that emerged as a result of modernity are especially concentrated in his poems Tufandan Önce and Sonumuz Bu Mu. The focus of study was these questions and criticisms; With the various theories produced in the context of the consequences of modernity, the relationship seen in Cumalı's poems was emphasized. In addition, intertextual relationship that poet established with dystopic novels such as 1984 and Brave New World was also taken into consideration, and modernity conditions and practices emphasized by Cumalı were determined in line with the studies aimed making sense of modern world both theoretically and fictionally. At this point, together with theories such as the surveillance society and consumer society, poems were examined within the framework of concepts such as daily life, media, panopticon, security, risk, commodification, sexuality, loneliness and alienation that came to the fore in relation to modernity.
\end{abstract}

Keywords: necati cumalı, poem, critism of modernity, consequences of modernity. 


\section{arts $s$}

\section{GíRiş}

Necati Cumalı, yazın hayatı boyunca şiir, hikâye, roman, tiyatro gibi farklı türlerde birçok eser yazmıştır. Her ne kadar farklı türlerde eserler yazmış olsa da gerek şair olarak gerek romancı gerekse oyun yazarı olarak gördüğümüz Cumall, gerçeğin peşinde bir sanatçı kimliğiyle karşımıza çıkar. Onun eserlerinde öncelikli olarak çevresinin, toplumun, zamanın gerçekliği ön plandadır. Cumalı, eserlerinde her zaman anlamı önemsemiş, anlamın üstünü örtecek veya anlamın anlaşılırlığını zorlayacak biçimsel denemelerden uzak durmuştur. Nitekim yazmaktaki amacının gerçeği yansıtmak, çeşitli sorunları dile getirmek olan bir sanatçının içerikten ziyade biçime önem vermesi de çok fazla rastlanılan bir tercih değildir. Bu hususta Cumalı, sanatta toplumsal fayda işlevini savunan yazarlardandır. Bundan dolayıdır ki Cumalı, neredeyse bütün eserlerinde insanı, toplumu öne çıkarmış, gerektiğinde eleştirmiş gerektiğinde çeşitli sorunları gündeme taşımıştır. Her gruptan ve sınıftan insanın yaşamına yer veren yazar, özellikle de köy, kasaba insanının yaşamına eğilmiş, yine bu insanların kentteki durumlarına, karşılaştıkları zorluklara ayna tutmuştur. Genel bir ifadeyle Cumalı, zamanının ve çevresinin sanatçısı olmuştur. Zamanına ve çevresine bakarak, anlayarak eserler vermiş, bu noktada da eserlerinin eleştirel yönü öne çıkmıştır. Cumalı, siyasetten ekonomiye, kültürden edebiyata yaşamın içerisinde gördüğü aksaklıkları, bozulmaları, yanlışlıkları eleştirmiş, olması gerekenin altını çizmiştir.

Yazın hayatına şiirle başlayan ve şiirden hiçbir zaman vazgeçmeyen Cumalı, ilk dönemlerinde Garip Akımı çizgisinde şiirler yazmıştır. Zamanla bu akımdan uzaklaşan Cumalı, kendi şiir anlayışı çerçevesinde üslubunu bulmuş, neredeyse hiçbir akımın ve şairin etkisinde kalmamıştır. Şiirlerinde yer yer toplumcu gerçekçiliğin ve eleştirel gerçekçiliğin izleri görülse de tam olarak bu akımların ve anlayışların da içine dahil edilebilecek bir şair değildir. Onun gerçekçiliği, kendi ifadesiyle "insancıl gerçeklik"tir. "Ben insancıl bir değer aradım yazdıklarımda. İnsancıl gerçek önemli. Ya bir garibanın savunması ya bir zalimin teşhiri. Benim için bunlar önemli" (Akçaoğlu, 2003, s. 37). Dolayısıyla Cumall, gerçeği herhangi bir ideoloji çerçevesinde yorumlamamış, gerçeği tarafsız, insancıl bir yaklaşımla ele almıştır. Zamanına ve çevresine bu nazarla yaklaşan Cumalı, Tufandan Önce (1983) başlığı altında topladığı şiirlerinde de gerçekliğin üstünde durmuş, modernliğin ortaya 
çıkardığı gerçekliği teşhir etmiştir.

1983 yılında yayımlanan bu şiirlerinde Cumalı, modernlik sonrası gelişen kent yaşamı, teknoloji, tüketim kültürü, endüstri toplumu gibi gelişmelerin insanın günlük yaşamındaki etkilerine odaklanmıştır. Gördüğü gerçeklikleri eleştirel bir tutumla değerlendiren şair, zamanın getirilerinin insan yaşamı, insan doğası ve insanın iç dünyasındaki etkilerini irdelemiştir. Bir başka ifadeyle modernliğin sonuçlarını eleştiren Cumalı, yine herhangi bir ideolojinin ya da kolektif hareketin doğrudan etkisinde kalmadan eleştirmiş, durumun insan hayatındaki olumsuzluklarını ortaya çıkarmak istemiştir. Bu amaç ve yönelim sonucunda ortaya çıkan şïlerde, modernliğin sonuçlarına yaklaşım, gündelik hayat, tüketim toplumu, gözetim toplumu, gibi modernlikle birlikte ortaya çıkan yeni koşulları anlamlandırmak için öne sürülen teorilerle benzerlikler gösterir. Ayrıca Orwell'ın 1984 (2019) ve Huxley'in Cesur Yeni Dünya (2020) adlı distopik romanlarıyla söylem düzeyinde metinlerarası bir çağrışım da dikkatleri çekmektedir. Bu benzerlik ve çağrışımlar özellikle de Tufandan Önce ve Sonumuz Bu Mu şiirlerinde yoğunlaştığı için Cumalı'nın modernliğe karşı yaklaşımı bu şiirler üzerinden incelenecek, modernliğin sonuçları bağlamında, özgürlük, güven, tüketim, gözetim, teknoloji, medya gibi kavramların modern insanın yaşamındaki etkileri irdelenecektir.

\section{Modernliğin Sonuçları Karşısında Necati Cumalı}

Modernliğin sonuçları, siyasetten ekonomiye, sanattan teknolojiye, dinden mimariye, gündelik hayattan iletişim, ulaşıma kadar uzanan geniş bir zemine yayılmıştır. Ortaya çıkan sonuçlar içerisinde olumlu, yapıcı olanlar kadar olumsuz, yıkıcı olanlar da vardır. Nitekim sanayileşme, kentleşme, teknolojikilerleme, kapitalizm gibi modernleşmeyle birlikte bireylerin ve toplumların yaşamında yer edinen olguların sonuçları öngörülemeyen felaketlere sebep olmuştur. Özellikle de Birinci ve İkinci Dünya savaşları, modern yapılanmaların yıkıcı yönlerini ön plana çıkarmış, modernliğin sorgulanmasına zemin hazırlamıştır. Savaşlar modern teknolojinin ölümcül yanını ortaya çıkarırken, sanayileşme makineleşmeyi, kentleşme yalnızlık ve yabancılığı, kapitalizm ise metalaşmayı hızlandırmıştır. Dolayısıyla da modernlik artık insanlık geleceği için büyük umutlar vadeden bir olgu olmaktan çıkmış, sorgulanan, eleştirilen, bir sorunsala dönüşmüştür. Başka bir ifadeyle aydınlanma düşüncesinin yerini, korku, endişe, tehlike, risk, gözetim, tahakküm gibi olgular almıştır. Nihayetinde 


\title{
$\operatorname{arts}=$
}

modernlik düşüncesiyle öngörülenler olmamış, bir zamanlar savunulan modernlik savunanların dahi eleştirdiği bir noktaya gelmiştir.

19. yüzyılın ortalarında gelecek hülyalarına kapılan entelektüeller, 20. yüzyıl ortalarında da o derece felaket, anlamsızlık ve tarihsel edimcilerin yok oluşu duygusunun etkisinde kalmışıı. Fikirlerin dünyayı yönettiğine inanmışlardl; sonuç olarak barbarlığın, mutlak iktidarın ya da tekelci devlet kapitalizminin önlenemez yükselişini mahkûm eder hâle geldiler (Touraine, 2018, s. 172).

Bu noktada katı olan her şeyin buharlaşması, kutsal olan her şeyin dünyevileşmesi, dünyanın büyüsünün bozulması gibi tespitlerle modernlik eleştirilmiştir. Modernliğin sonuçları doğrultusunda ortaya çıkan en temel olgu değişim olmuştur. Antony Giddens (2012), modernliğin sonuçlarını tartışırken bu değişimle birlikte güven, risk, tehlike gibi kavramlara dikkat çeker ve ortaya çıkan yeni durumlar karşısında birey ve toplumların karşı karşıya kaldığı yeni koşulları irdeler. Genel itibariyle yeni yaşam tarzlarına odaklanan Giddens'ın ilk tespiti, modernliğin süreksizliğinden kaynaklı tarihsel kopuştur.

\begin{abstract}
Modernliğin sonucunda ortaya çıkan yaşam tarzları bizi geleneksel toplumsal düzen türlerinin tamamından eşi görülmedik bir biçimde söküp çıkarmıştır. Modernliğin getirdiği dönüşümler hem yaygınlıkları hem yoğunlukları açısından önceki dönemlere özgü değişim biçimlerinin çoğundan daha etkilidirler. Yaygınlık düzleminden bakıldığında bu dönüşümler küresel düzeyde toplumsal bağlantı biçimleri kurulmasında etkili olmuşlardır; yoğunluk açısından ise günlük yaşamımızın en özel ve kişisel özelliklerini değiştirme aşamasına gelmişlerdir (Giddens, 2012, s. 12).
\end{abstract}

Cumalı'nın şiiri de tam olarak bu noktaya değinir ve modernliğin sonuçları doğrultusunda ortaya çıkan yeni bireyi, toplumu ve gündelik yaşamı sorgular. Özellikle de Tufandan Önce başlıklı şiirinde, teknoloji, medya, kapitalizm gibi somut ve soyut olguların birey üzerindeki etkisini ön plana çıkarır. Şair, şiirin birinci bölümünde medya araçları ile bireyin ve toplumun gözetim altına alınarak nasıl yönlendirildiğine değinir.

\section{TUFANDAN ÖNCE}

$\begin{array}{ll}\text { Sabah gazeteleriyle çalıyorlar kapımızı } & \text { Üstümüze üstümüze geliyor } \\ \text { Radyo ile TV ile giriyorlar odalarımıza } & \text { Buluyor bizi yerleşiyorlar } \\ \text { Sokağa çıksak rahat bir merhaba } & \text { Beyinlerimizin içi pazaryerleri } \\ \text { Dediğimiz yok birbirimize } & \text { Baş yastıklarımızın altı hanları otelleri }\end{array}$




\section{$\operatorname{arts}=$}

Eve girsek karı koca çoluk çocuk

Karşılıklı ne dediğimizi duyamıyoruz

Önümüzde ardımızda karaltılar gölgeler

Kulaklarımızda sesleri gürültüleri

Hanidir ses hızını aştılar

Dünyanın dört bir ucundan çıkıyor yola
Not defterlerimizin yapraklarına uzanmışlar

Sayfayı çevirsek kalkıp doğruluyorlar

Telefonu açtık mı alıcıda sesleri

İsaret parmakları gözlerimizin içinde

Nedense kaşları her zaman çatık

Söyledikleri her söz azar

(Cumalı, 1983, s.9).

Buradaki gözetim, ilk olarak akla Orwel'ın 1984 (2019) distopyasını akla getirir. Şiirin 1983 yılında yazıldığı da dikkate alındığında Cumalı'nın radyo, gazete, televizyon gibi medya araçlarını Orwel'ın, her şeyi gören, herkesin hayatına yön veren Büyük Birader'ine akla getirir. Cumalı da diğer birçok yazarın hissettiği gibi, modern dünyanın yeni şartlarını kuşatıımışlık olarak yorumlar. Burada şair, modernliğin sonucu olarak ortaya çıkan gözetim toplumu olgusuna dikkat çeker.

Bu bağlamda, sistematik gözetim pratiklerinin ilk olarak modernizm ile ortaya çıktığını ve gözetime yönelik eleştirilerin temellerinin de modernizm ile birlikte ałıldığını söylemek mümkündür. Illk olarak modernizmin temsilcilerinden ve önde gelen düşünürlerinden Karl Marx, daha sonra Max Weber, Frederick W. Taylor ve Anthony Giddens, gözetim pratiklerini modernizm ekseninde ele alıp tartışmışlardır. Sonrasında ise, ünlü romancı George Orwell'ın 1948 yılında yazın alanına kazandırdığı bir 'korku ütopyası' (distopya) olan '1984' isimli kült eserinde edebî bir kavramsallaşmaya ulaşan gözetim olgusu, 20. yüzylın en önemli postmodern düşünürlerinden biri olarak değerlendirilen Michel Foucault tarafından ayrıntılı şekilde irdelenerek olgunluk kazanmıştır. Modernizm ve postmodernizmde farklı açılardan yorumlansa da temel olarak gözetimi, egemen ideolojinin arzu ettiği denetimi ve disiplini sağlayarak hegemonyanın devam etmesine yönelik sistematik bir süreç olarak tanımlamak mümkündür (Okmeydan, 2017, s. 55).

Şiirin devamında da gözetimle birlikte gelen bu disipline etme ve denetimi sağlama çabasına vurgu yapılır.

\author{
İndir yakalarını \\ Şapkanı çıkar! \\ You! \\ İş bulma kurumu önünde \\ Sol baştan birinci \\ Serseri kerata \\ Yürü \\ Saçlarını kestireceğiz!
}

\author{
Aranan biri için \\ Karakolda \\ Tanıklık edeceksin! \\ Yazgımız üstüne fiş düzenliyor \\ Pey sürüyor zar atıyorlar \\ Bakınma öde, \\ Bağıra çağıra dinletiyorlar \\ Duymak işitmek istemediklerimizi
}




\section{arts $=$}

You:

Süpermarket kasası kuyruğunda

Dikilen bayan

Ne duruyorsun

Duymadın mı

Yürü düş önüme
- Aldınız mı hayvan oğlu hayvanlar

Alin almadinızsa!

Daha da kafaları kızarsa

Çıkarıp gösteriyorlar göstereceklerini!

(Cumalı, 1983, s. 10).

Bu dizelerde yine 1984 romanında gördüğümüz, bireylerin iktidar tarafından sürekli gözetilmesi, bireylere nerede ne yapması gerektiğini söyleyerek toplumu belli bir düzen içerisinde otomatlaştıran yapıya benzer bir oluşumu görürüz. Şiirde "you" ifadesiyle emir veren otorite, 1984 (2019) romanındaki "Big Brother is Watching You" (Orwell, 2019) diyen otoriteye benzer. Hem 1984'teki otorite hem de Cumalı'nın şiirindeki otorite aynı amacı taşımaktadır. Bu amaç, toplumu gözetim altına tutarak disipline etmek, yönlendirmektir. Cumalı da "you" ifadesiyle medya ve diğer organlarca kapitalizmin tüketime yönlendirdiği bireyi vurgular.

Cumalı'nın şiirle ifade ettiği bu gözetim ve disipline etme olayını, bazı araştırmacılar panoptikon kavramıyla açıklamışlardır.

Günümüzde iktidarların işleyiş mekanizmasını kavramak için Bentham tarafından ortaya atılan ve Foucault'nun söyleminde derinlik kazanan panoptikon metaforu, bilgi iletişim teknolojileri ile kuşatılmış bugünün dünyasını yorumlamada pratik bir kavrayış sunmaktadır. Bentham'ın metni, kapitalizm ile birlikte toplumsal iktidarın geçirdiği yapısal dönüşüme gönderme yapmaktadır. Bu gönderme, egemen güç olan iktidarın hegemonyasını yaygınlaştırmak için, toplumdaki her bireye sınıları yine iktidarın otoritesi tarafından belirlenmiş 'özgürlük sanrısı' içerisinde hareket etmesine olanak veren bir ortamı ifade etmekte ve yerel bir gözetim işlevini yerine getirmektedir (Okmeydan, 2017, s. 58).

Dolayısıyla burada panoptikon işleviyle yer alan unsur teknolojik iletişim ve medya araçlarıdır. Tıpkı Orwel'ın 1984 (2019) adlı romanında panoptikon işlevi gören "tele-ekran" gibi, Cumall'nın şiirinde de radyo, televizyon gibi araçlar bireylerin en özel anlarına dahi şahit olmakta, bununla da yetinmeyip bireyleri belli bir günlük yaşama zorlamaktadır. Orwell komünist rejim tarafından gözetlenen bireyin kuşatıımışlığını anlatırken Cumalı, kapitalizm tarafından gözlenen, belli bir yaşam biçimine yönlendirilen bireyi ve toplumu anlatır. 


\section{$\operatorname{arts}=$}

Cumalı modernliğin sonuçlarını eleştirirken gözetim toplumu teorisiyle birlikte, Lefebvre'nin Gündelik Hayat (2007) teorisine de yaklaşır. Cumalı, yukarıdaki dizelerde de çağrışııııdığı gibi gündelik hayatın çeşitli otoritelerin ve kurumların elinde yönetilebilen bir düzen olduğunu söyler. Lefebvre ise gündelik hayat olgusunu şöyle açıklamıştır:

Gündelik hayat, artık itinayla incelenen bir nesne olmuştur: örgütlenmenin alanı, iradi ve planlı bir öz-düzenlemenin uzay-zamanı haline gelmiştir. Örgütlenen gündelik hayat, kapalı bir devre (üretim-tüketim-üretim) haline gelmiştir. Önceden biçimlendirilen gereksinimlerin ne olacaklarını tahmin etmek artık işten değildir; arzuların ise izi sürülür. Rekabetçi dönemdeki kendiliğinden ve körü körüne öz-düzenleme süreçlerinin yerini bu olgu alır. Böylece gündeliklik kısa sürede, sistematikleştiren düşüncenin ve yapılandırıcı eylemin hedeflediği diğer sistemlerin altında gizlenen biricik sistem, kusursuz sistem haline gelecektir. Bu sıfatla gündeliklik, örgütlenmiş ya da tüketime yönlendirilmiş diye tanımlanan toplumun ve onun dekorunun, yani modernliğin temel ürünü olacaktır (Lefebvre, 2007, s. 86).

Kapitalist yapılanma içerisinde gerek gözetimin gerekse gündelik hayatın özellikle de kontrol edebilme ve tüketime yönlendirme işleviyle yeni boyutlar kazandığı görülür. Bir yandan günlük hayat düzenlenip belli bir sisteme ulaştırılırken bir yandan da bireyler birtakım intiyaçlara, arzulara, hobilere yönlendirilir. Cumalı da şiirin olanakları içerisinde şu dizelerinde bu yönlendirmeye ve düzenlemeye değinir:

$\begin{array}{ll}\text { Yüzde on ön ödeme } & \text { Sizin gazeteniz! } \\ \text { Gerisi on üç ay taksitle } & \text { Reklam dizi film } \\ \text { Atın değiştirin düşünmeyin! } & \text { Reklam dizi film } \\ \text { Sevdiğimiz saydığımız } & \text { Haberler } \\ \text { Bütün sahne sanatçıları } & \text { Merakla dinlersin } \\ \text { Kapılarında çağırtkan } & \text { Boşuna! } \\ \text { Sizin bankanız } & \text { (Cumalı, 1983, s. 11) } \\ \text { Sizin buzdolabınız } & \end{array}$

Modern bir bireyin günlük yaşamına değinilen bu dizelerde gerek bireyin gerekse yaşamının düzenlenmiş bir nesne haline geldiği görülür. Şairin öne çıkardığı gibi birçok araştırmacı da bu noktada iletişim ve medya araçlarını öne çıkarmıştır. Bu hususta Douglas Kellner (2013) medyanın bireyler üzerindeki etkisine yöneldiği çalışmasında, medya araçlarının insanları tüketime yönlendirdiğini savunur. 


\section{arts}

Kellner'a göre "Televizyon, seyircisiyle ilk defa tanıştığı 1940'lı yıllardan beri arabalar, moda, mobilyalar ve diğer ürünlerle birlikte tüketicilere yaşam tarzları ve değerler benimseterek tüketim gösterisinin kurucusu ve destekleyicisi olmuştur" (Kellner, 2013, s. 30). Dolayısıyla burada bireyin özgürlüğünden bahsetmek, yeni yaşam biçimi içerisinde bireyin özne olarak rol aldığını savunabilmek zorlaşır. Nitekim modern kapitalist toplumda bir "homo economicus" yaratılırken, seçimler ve düzenler de bireylere dayatılan bir pratik haline gelir. Tüketim Toplumu (2008) savunucularından Jean Baudrillard bu durumu şöyle izah eder:

Tüm bir özgürlük uygarlığının doruk noktasına ulaştığı bu tatmin ve bireysel seçim aldatmacası bizzat sanayi sisteminin ideolojisidir, sanayi sisteminin keyfiliği ve toplumsal zararlarının tamamı bu ideolojiyle aklanır. Soysuzluk, kirlilik, kültürsüzleşme; aslında tüketici kendisine seçme özgürlüğünün dayatılığı balta girmemiş iğrençlik ormanında egemendir (Baudrillard, 2008, s. 83).

Bu sebeple modern özgürlüğün, seçimin bir aldatmacadan ibaret olduğunu, bireylerin çeşitli araçlar ve kurumlarla belirli bir yaşama yönlendirildiği söylenebilir. Varoluşsal sorunları da beraberinde getiren bu durum, bireyin hatta toplumun yitimini hızlandıırmıştır. Nitekim edebiyat ve sanat eserlerinde de sorgulanan modernliğin bu sonucu, genellikle güvensiz, riskli, tehlikeli ve endişe verici olarak anlatılara yansımışıı. Sadece 1984 (2019) ya da Cesur Yeni Dünya (2020) gibi distopik eserlerde değil, Cumalı'nın şiirinde olduğu gibi, zamanına ayna tutan, içinde bulunduğu toplumun yaşamına odaklanan sanatçılar da bu durumu görmekte ve endişelerini belirtmektedir. Modern eserlerin birçoğunda modernlik sonucu ortaya çıkan yalnızlığa, yabancılaşmaya, tahakküme karşı bir direnç, isyan söz konusudur. "Modernitenin dayatmaları tarafından ele geçirilmeyi kabullenemeyen şair, kendisini başkalaştırmaya/yalnızlaştırmaya çalışan her şeye karşı bir reddediş içindedir. Bu reddediş, statik değil dinamiktir. Zira zamanın hızına ve modernizmin değişkenliğine yetişemeyen birey, dar bir çerçevenin içinden sıyrılmak için başkaldırı içeren bir tepki gösterir" (Kanter, 2011, s. 34). Cumalı'da bu şiirinde önce bir durumu tespit etmiş daha sonra da ortaya çıkan sonuçları bir bir sıralayarak tepkisini belirtmiştir.

Teknoloji, kapitalizm, tüketim gibi olgular etrafında yeni oluşan kültürü, yaşamı eleştirmek isteyen Cumalı, şiirinin şu dizelerinde modern bireyin nasıl kuşatılığına, nasıl nesneleşip nasıl kendi ürettiklerinin altında ezildiğine dikkat çeker. 


\section{arts}

$\begin{array}{ll}\text { Rock rock rock every body } & \text { Bağır üstüne çektiğin } \\ \text { Roll/ roll/ roll/ every body } & \text { Kapattığın yapay göklerine } \\ \text { Oooooo my baby! } & \text { Loş diskoteklerin } \\ \text { Bağır karanlıklarına gecelerin } & \text { Ya da beton demir kafeslerinde } \\ \text { Kalabalıkların burgacında boğul } & \text { Yüz binlik tribünlerin } \\ \text { Yumurta kadar yüreğinde } & \text { Goool, goool, gooool! } \\ \text { Yanardağ gibi kabaran öfke } & \text { Sen yarattın bütün devlerini } \\ \text { Can sıkıntına bunalımına ezilmişliğine } & \text { Sen tutsak düşłün ellerine! } \\ \text { Marivana LSD } & \text { (Cumall, 1983, s.13). }\end{array}$

Şiirin tamamında olduğu gibi bu bölümünde de neden-sonuç ilişkisi söz konusudur. Ortaya çıkan yeni şartlar, durumlar ve üretimlerin sonucunda bireyin kısıtlanmış, parçalanmış, hatta yozlaşmış bir düzen içerisindeki kayboluşu hikâye edilir. Bu noktada rock müziğe, diskoteklere, futbola değinen şair, modernliğin sonucunda ortaya çıkan küreselleşme ile kültürün, insanın yozlaşmasına da gönderme yapar. Bellidir ki şair bu değişimden rahatsızdır ve endişe duymaktadır. Burada modernliğin bütün alanlarda görülen sonuçlarına karşı bir duruş da söz konusudur. Nitekim şair de bu zamanı yaşamakta, modernliğin endişe verici havasını solumaktadır.

Ayrıca bu bölümdeki "Yumurta kadar" ve "Can sıkıntına bunalımına ezilmişliğine/ Mariuana Lsd" ifadeleri metinlerarası düzlemde Huxley'in Cesur Yeni Dünya (2020) distopyasını çağrıştıır. Cesur Yeni Dünya'da insanlar tıbbi laboratuvarlarda oluşturulan yumurtalardan çıkmaktadır. Yetişkinliklerinde ise mutluluk ilacı olarak "soma" adında haplar kullanırlar. Tamamen yapay bir dünyada köleliklerini sevmeye şartlandırılan insanlar, Kuluçka ve Şartlandıma Merkezi'nde kendileri için uygun görülen rollerini benimserler. Burada Cumalı'da diskoteklerde, beton kafeslerdeki insanların yapay bir zeminde yaşadıklarına ve kendilerini mariuana ile mutlu hissetmeye çalıştıklarına değinir. Dolayısıyla burada yine endişe verici bir bilinçsizlik, yapay bir mutluluk söz konusudur. Devam eden dizelerde bu endişeye ek olarak modern teknolojilerin kullanılmasıyla ortaya çıkan güvensizlik de eklenir. 


\section{$\operatorname{arts}=$}

$\begin{array}{ll}\text { Atomu kullanmak } & \text { Binlerce yıldı̈ ölürsün } \\ \text { Öldürücü silahlarda } & \text { Sağ kalır cellatların ardında! } \\ \text { Nötron bombası } & \text { Ey bu kuşkulu çağın } \\ \text { Toptan yok etmek hepimizi! } & \text { Güvensiz günlerin } \\ \text { Kim etmiştir } & \text { Garip insanı }\end{array}$

(Cumall, 1983, s.14).

Şairin bu korkusu ve endişesi, İkinci Dünya Savaşı gibi bir felaketi yaşamış, nükleer silahların ne derece etkili olabileceğini bilen herkesin paylaşabileceği bir endişe ve korkudur. "Bugün içinde yaşadığımız dünya çok gergin ve tehlikelidir. Böylesi bir durum, modernliğin ortaya çıkışının daha mutlu ve güvenli bir düzenin oluşumuna yol açacağına ilişkin varsayıma inanmak yolunda hevesimizi kırmak ya da zorlamaktan da fazlasını yapmış bulunmaktadır" (Giddens, 2012, s. 16). Dolayısıyla şairin dediği gibi insan, kendi aklıyla ürettikleri karşısında endişe ve korku içerisindedir. Sadece silahlar değil, sanayileşme, kentleşme, dijitalleşme, robotlaşma gibi endüstriyel bir yaşamın olumlu sonuçları kadar olumsuz, yıkıcı sonuçları da olmuştur. "Nükleer savaş olasılığı, ekolojik yıkım, engellenemeyen nüfus patlaması, küresel ekonomik mübadelenin çöküşü ve diğer gizil küresel felaketler herkes için cesaret kırıcı bir tehlike ufku oluşturmaktadır" (Giddens, 2012, s. 110). Cumalı da bu tehlikeyi görmüştür ve yukarıdaki dizelerde nükleer silahlara, felaketlere değinirken şiirin devamında endüstri toplumu içerisinde yitip giden insana değinir.

$\begin{array}{ll}\text { Yeryüzünde çoğaldıkça } & \text { Endüstri çağı başında } \\ \text { Ters bir oranla } & \text { Milyarda bir } \\ \text { Azalan bir sen varsın } & \text { On milyarda bir } \\ \text { Milyonla sayılırdın } & \text { Günümüzde } \\ \text { Eski çağlarda } & \text { Yani bir çeşit kumu } \\ \text { Milyonda 'birdin } & \text { Bir tür karıncasııın } \\ \text { Artık sen de } & \text { Ambalajlanıyor } \\ \text { Bu yaşlı dünyanın } & \text { Sunuluyor sana } \\ \text { O, ben ben dediğin nesne } & \text { Her geçen gün biraz daha } \\ \text { Bunca saydığın öğündüğün } & \text { Beyin yıkama yollarıyla } \\ \text { Uğrunda kılıç çektiğin kişiliğin } & \text { Endüstriyel haplara benziyorsun! } \\ \text { Nikelajılı kağıllara sarılıyor } & \text { (Cumalı, 1983, s.15). }\end{array}$




\section{$\operatorname{arts}=$}

Şaire göre nicelik olarak çoğalan insan, nitelik olarak azalır. Çünkü insan kendi ontolojik bağlamından uzaklaştııımış, metalaşmış ve bir nesne haline getirilmiştir. Endüstriyel yaşamın üretim-tüketim döngüsü içerisinde insan da tükenmeye başlamıştır. Tüketim toplumu ve kültürü içerisinde bir homo economicus olarak düzenlenen insan öğesi, metalaşmıştır. Yine burada Cesur Yeni Dünya (2020) romanıyla bir dirsek teması hissedilir. Yukarıda da değinildiği gibi, bu romanda insanlar endüstriyel ortamlarda üretilir ve şairin de dediği gibi, "endüstriyel haplar" gibi, son derece yapay ve mekaniktirler. Duygusal olarak içleri boşaltılmış insanlardır ve din, tarih, edebiyat, doğa, aşk gibi unsurlardan da soyutlanmışlardır. Cumalı'nın modern insanı da endüstri dünyasının bir ürünü olarak maddeleşmiş, manevi ve ruhani olarak azalmıştır. İnsandan geriye sadece madde kalmış, madde ile var olma çabaları neticesinde de elinde ancak cinselliği kalmıştır. Başka bir ifadeyle modern insan cinselliğe yönlendirilerek avutulmuştur.

$\begin{array}{ll}\text { Mutluluk diye } & \text { Geziye çağıııor turizm acentaları } \\ \text { Bir cinselliğin kaldı elinde } & \text { Denizcilik işletmeleri } \\ \ldots & \text { Uçak ortaklıkları } \\ \text { Hamburg'ta genel evler mallarını } & \text { Daha çok çiftleşerek } \\ \text { Vitrinlerde sergiliyor } & \text { Daha çok unutarak } \\ \text { Kopenhag'ta canı sıkılanlar } & \text { Mutlu olabilirsiniz } \\ \text { Bırakıp deniz 'kıyılarını parkları } & \text { Boşverin sevgiyi mevgiyi! } \\ \text { Cinsellik fuarında tur atıyorlar } & \text { (Cumalı, 1983, s. 17). } \\ \text { Çıplak güzellerin fotoğraflarılyla } & \end{array}$

Cinselliğin, kadın bedeninin tüketilmesini de düzenlenmiş bir yaşam pratiği içerisinde bir nevi uyuşturucu gibi değerlendiren Cumalı, bir yandan yine tüketime vurgu yaparken bir yandan da maddileşmiş dünyada mananın, soyut değerlerin nasıl geri planda kaldığına değinir. Cinselliğin çeşitli araçlarla görünür kılınması, öne çıkarılması da çeşitli araştırmalara göre sistematik bir yönlendirmedir. "Erotizm, çoğunlukla Batı kültüründe gösterilerin içine işlemiştir ve Hollywood sinemasında göze çarptığı kadar reklamlarda, kulüplerde ve pornografide de karşımıza çıkmaktadır. Uzun zamandır reklamcılığın önemli parçası olan erotikleştirilmiş cinsellik, uygun olan 


\section{$\operatorname{arts}=$}

her ürünün satılması için kullanılmaktadır" (Kellner, 2013, s. 35). Bu noktada özellikle kadın bedeninin teşhiri ve tüketim amaçlı kullanılarak sömürülmesi, Lefebvre'ye göre de kadının nesneleştirilmesini sağlamışır.

Kadınlar gündeliklik içinde hem öznedirler hem de gündelik hayatın kurbanlarıdırlar, dolayısıyla nesnedirler, ikamedirler (güzellik, dişilik, moda, vs.); üstelik, ikamelerin çoğalmaları kadınların aleyhinedir. Kadın aynı zamanda hem alıcı hem de tüketicidir hem metadır hem de metanın simgesidir (reklamlardaki çıplak beden ve gülümsemedir) (Lefebvre, 2007, s. 87).

Cumalı'ya göre de dayatılan bu cinsellik, endüstriyel yaşamın küçülttüğü, yok ettiği insana bıraktığı tek mutluluk kaynağıdır. Foucault'nun da dediği gibi "bir kaygı ve analiz nesnesi haline gelen cinsellik, herkesin kendi bedeni için kendi bedeninde ve kendi bedeni üzerinde duyduğu arzuların yoğunlaşmasına yol açmışı"ı" (Foucault, 2015 , s. 40). Dolayısıyla en sonunda insan da maddeleşir ve sadece bedeniyle var olabilen bir varlığa dönüşür. Hem kadın hem erkek bedeni cinsel amaçlı sergilenerek tüketilen bir objeye dönüşür. Şiirin isminde de vurgulandığı gibi tüm bunlar bir tufana işarettir. Şair, tufandan önceki son durumun karamsar tablosunu resmeder.

Tufandan Önce şiirinde modernliğin tablosunu çizen Cumalı, bu gelişmelerin insanlığın doğasındaki sonuçlarını ise Sonumuz Bu Muydu şiirinde dile getirir. İlk dizelerde modernlik sonrasında varılan noktanın bir hayal kırıklığı olduğunu görürüz.

\section{SONUMUZ BU MU}

Çayırlar korular ekili yerler

Büyüklü küçüklü kentler geçtik

Yolun neresindeyiz şimdi

Bir çöl görüntüsü pencerelerde

Nereye gidiyoruz nereye gidecektik (Cumall, 1983, s. 37).

Bu hayal kırıkığı modernliğin sonuçları doğrultusunda birçok sanatçı ve aydının ortak duygusudur. Yukarıda da değinildiği gibi, modernite dünyayı daha mutlu, daha huzurlu bir yer yapmamıştır. Aksine, teknoloji, kapitalizm, kentleşme gibi olgular doğrultusunda birçok değerin içi boşalmıştır.

Gençlikte ne varsa inandığımız

lyyi doğru güzel bellediğimiz
Acımanın kapıları kapalı

Kaba kahkahalar sardı kenti 


\section{$\operatorname{arts}=$}

$\begin{array}{ll}\text { Kırıldı döküldü hoyrat ellerde } & \text { Açıklarda bırakıp tekneleri } \\ \text { Ayaklar altında çiğnendi şiir } & \text { Karalara dönen kuşlar gibi } \\ \text { Geçerli tek uyak paranın sesi } & \text { Işıklı günlerin alıın yüzleri } \\ \text { Ayaklar alıında kułsal ne varsa } & \text { Niye sustunuz bir bir uçup gittiniz } \\ \text { Dostluklar yeminler pörsümüş } & \text { Sonumuz acımasız dalgaların elinde } \\ \text { Aşklar kabuğu sıkılmış posa } & \text { Artan yalnızlıklara sürüklenmek mi } \\ \text { Kalpler sevgilere sağır } & \text { (Cumalı, 1983, s. 37). }\end{array}$

Cumalı' nın modernliğin sonucunda gördükleri olarak okunabilecek bu şiirde, "katı olan her şeyin buharlaştığını", "dünyanın büyüsünün bozulduğunu" ve "kutsal olan her şeyin dünyevileştiğini” açıkça görebiliriz. Nitekim iyi ve güzel olanın bir önemi kalmamış, değerler, inançlar, kutsallar teknoloji, para gibi unsurlar karşısında değersizleşmiştir. Bu durum büyük bir değişim sonucunda bozulmayı, tükenmeyi, yitip gitmeyi işaret eder. Nitekim şairin son dizede vurguladığı modern bireyin yalnızlığı da bu durumla ilişkilidir. Son derece maddileşmiş, nesneleşmiş, metalaşmış modern bireyin içine düştüğü yabanclık ve yalnızlık, yine insanın insan tarafından tahakküm altına alınmasıyla ortaya çıkmıştır. "Böyle bir tahakküm altındaki insan, dev makinelerin gıdası durumuna indirgendiği gibi ruhsal özünü yitirerek mekanikleşmiş ve modern yaşam örüntüleri arasında figürleşmiştir. Modernizmin değişkenliğinin baskısı altında ezilen birey, yalnızlığını giderememenin ve üstesinden gelemediği ruhsal çöküntülerinin sancısıyla çırpınır. Çünkü üretimi kolaylaştıran modern yaşam, aynı zamanda bir tehdittir" (Kanter, 2011, s. 33). Cumalı da insanın modernizm karşısında yitirdiği ruhsal özü aramakta; aşk, sevgi, merhamet, vicdan, kutsal değerler gibi insanın mana iklimini bertaraf eden modernliği eleştirmektedir.

\section{SONUÇ}

Cumalı, modernliğin sonucunda ortaya çıkan yeni durumu Tufandan Önce adlı şiirinde tespit ederken Sonumuz Bu Muydu şiirinde ise bu yeni durumun insan öznesinden neleri alıp götürdüğüne değinmiştir. Cumalı, tespitle birlikte yoğun bir eleştiriyi barındıran bu şiirlerinde, bireyin medya araçlarıyla gözetilip tüketime yönlendirilmesine, insanın teknolojik gelişmeler karşısındaki çaresizliğine ve bu gelişmeler doğrultusunda oluşan risk ve tehlikeye, kapitalizmin insan bedenini dahi metalaştırmasına, kitlelerin müzik, spor gibi çeşitli unsurlarla uyuşturulmasına 


\section{arts $=$}

ve en nihayetinde insani değerlerin bir bir yok olarak insanın yalnızlaşmasına, yabancılaşmasına odaklanmıştır. Cumalı'nın bu eleştirisi modernliğe karşı muhafazakâr bir eleştiriden ziyade, Marksist ve kısmen de postmodernist bir yaklaşımı içerir. Nitekim şair gözetilme, kontrol edilme ve tahakküm altına alınma eleştirileri ile Foucaoult'nun Hapishanenin Doğuşu (2019), iktidarın Gözü (2015) gibi bireyi kontrol altına alan modernliği eleştirdiği çalışmalarına yaklaşırken; gündelik hayatın çeşitli unsurlarla düzenlenmesine ve bu alanın üretim-tüketim-üretim döngüsü içerisinde örgütlenmesini eleştirirken Lefebvre'nin Gündelik Hayatın Eleştirisi'nde (2012) öne sürdüğü Marksist eleştiriye yaklaşır.

Modernliğin sonucunda ortaya çıkan yeni koşulları tufan öncesi son durumlara benzeten Cumalı, modernliğin radikal değişimleri karşısında korkulu ve endişelidir. Sonumuz Bu Muydu şiirinde de açıkça belirttiği gibi, değişimler sonucunda şairin gördüğü büyük bir yokluktur. Bu yokluk maddi dünyada zenginleşen insanın mana ve ruh dünyasındaki yoksulluğundan kaynaklıdır. İnsan, makinenin, teknolojinin, medyanın, beton duvarların, nükleer silahların dünyasında bir pazar nesnesi haline gelmiş, özünü kaybetmiştir. Modernlik dünyayı bir hapishaneye dönüştürürken insanı da bu hapishanenin mahkûmu yapmıştır. Dolayısıyla insan, sürekli gözlenebilen, yönlendirilen ve yeri geldiğinde alınıp satılabilen bir meta olmuştur. Bu noktadan yaklaşıldığında Cumalı şiirlerindeki modernlik eleştirisinin, birçok Marksist ve postmodernist eleştirmenin yukarıda andığımız çalışmalarındaki eleştirel görüşlerle paralellik içerdiği tespit edilmiştir.

\section{KAYNAKÇA}

Akçaoğlu,S. (2003). NecatiCumalı'nın Hikâye ve Romancılığı. (Yayımlanmamış Dokłora Tezi). Ankara Üniversitesi Sosyal Bilimler Enstitüsü, Ankara.

Baudrillard, J. (2008). Tüketim Toplumu (3. Baskı) (Çev. H. Deliçaylı ve F. Keskin). İstanbul: Ayrıntı.

Cumalı, N. (1983). Bütün Şiirleri 1. İstanbul: Yazko.

Foucault, M. (2015). İktidarın Gözü (4. Baskı) (Çev. I. Ergüden). İstanbul: Ayrıntı.

Foucault, M. (2019). Hapishanenin Doğuşu (4. Baskı) (Çev. M. A. Kılıçbay). Ankara: Imge. 
Giddens, A. (2012). Modernliğin Sonuçları (5. Baskı) (Çev. E. Kuşdil). İstanbul: Ayrıntı.

Huxley, A. (2020). Cesur Yeni Dünya (10. Baskı) (Çev. Ü. Tosun). İstanbul: İthaki.

Kanter, B. (2011). Turgut Uyar'ın Şiirlerinde Modern İnsanın Yalnızlığı ve Sonsuzluk Özlemi. Fırat Üniversitesi Sosyal Bilimler Dergisi, 21 (2), 26-38.

Kellner, D. (2013). Medya Gösterisi (2. Baskı) (Çev. Z. S. Doğruer). İstanbul: Açlım.

Lefevbre, H. (2007). Modern Dünyada Gündelik Hayat (2. Baskı). (Çev. I. Gürbüz). İstanbul: Metis.

Lefebvre, H. (2012). Gündelik Hayatın Eleştirisi 1 (1. Baskı) (Çev. I. Ergüden). İstanbul: Sel.

Okmeydan, S. (2017). Postmodern Kültürde Gözetim Toplumunun Dönüşümü: 'Panopticon'dan' 'Sinopticon ve Omniptikon'a'. AJIT-e: Online Academic Journal of Information Technology, 8(30), 45-69.

Orwell, G. (2019). 1984 (71.Baskı) (Çev. C. Üster). İstanbul: Can.

Touraine, A. (2018). Modernliğin Eleştirisi (11. Baskı) (Çev. H. Tufan). İstanbul: Yapı Kredi. 